2014s-16

\title{
General Equilibrium Effects of Green Technological Progress
}

Ngo Van Long, Frank Staehler

\begin{tabular}{c}
\hline Série Scientifique \\
Scientific Series
\end{tabular}

\section{Montréal \\ Février 2014/February 2014}

(C) 2014 Ngo Van Long, Frank Staehler. Tous droits réservés. All rights reserved. Reproduction partielle permise avec citation du document source, incluant la notice $\odot$.

Short sections may be quoted without explicit permission, if full credit, including @ notice, is given to the source.
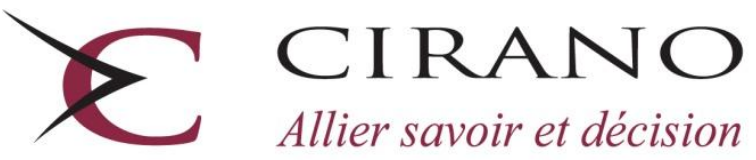

Allier savoir et décision

Centre interuniversitaire de recherche en analyse des organisations 


\section{CIRANO}

Le CIRANO est un organisme sans but lucratif constitué en vertu de la Loi des compagnies du Québec. Le financement de son infrastructure et de ses activités de recherche provient des cotisations de ses organisations-membres, d'une subvention d'infrastructure du Ministère de l'Enseignement supérieur, de la Recherche, de la Science et de la Technologie, de même que des subventions et mandats obtenus par ses équipes de recherche.

CIRANO is a private non-profit organization incorporated under the Québec Companies Act. Its infrastructure and research activities are funded through fees paid by member organizations, an infrastructure grant from the Ministère de l'Enseignement supérieur, de la Recherche, de la Science et de la Technologie, and grants and research mandates obtained by its research teams.

\section{Les partenaires du CIRANO}

\section{Partenaire majeur}

Ministère de l'Enseignement supérieur, de la Recherche, de la Science et de la Technologie

\section{Partenaires corporatifs}

Autorité des marchés financiers

Banque de développement du Canada

Banque du Canada

Banque Laurentienne du Canada

Banque Nationale du Canada

Banque Scotia

Bell Canada

BMO Groupe financier

Caisse de dépôt et placement du Québec

Fédération des caisses Desjardins du Québec

Financière Sun Life, Québec

\section{Gaz Métro}

Hydro-Québec

Industrie Canada

Investissements PSP

Ministère des Finances et de l'Économie

Power Corporation du Canada

Rio Tinto Alcan

Transat A.T.

Ville de Montréal

\section{Partenaires universitaires}

École Polytechnique de Montréal

École de technologie supérieure (ÉTS)

HEC Montréal

Institut national de la recherche scientifique (INRS)

McGill University

Université Concordia

Université de Montréal

Université de Sherbrooke

Université du Québec

Université du Québec à Montréal

Université Laval

Le CIRANO collabore avec de nombreux centres et chaires de recherche universitaires dont on peut consulter la liste sur son site web.

Les cahiers de la série scientifique (CS) visent à rendre accessibles des résultats de recherche effectuée au CIRANO afin de susciter échanges et commentaires. Ces cahiers sont écrits dans le style des publications scientifiques. Les idées et les opinions émises sont sous l'unique responsabilité des auteurs et ne représentent pas nécessairement les positions du CIRANO ou de ses partenaires.

This paper presents research carried out at CIRANO and aims at encouraging discussion and comment. The observations and viewpoints expressed are the sole responsibility of the authors. They do not necessarily represent positions of CIRANO or its partners. 


\title{
General Equilibrium Effects of Green Technological Progress
}

\author{
Ngo Van Long ${ }^{*}$, Frank Staehler ${ }^{\star}$
}

\begin{abstract}
Résumé/abstract
Cet article démontre que les progrès technologiques dans la production d'énergie renouvelable peut influencer la trajectoire de l'extraction de combustibles fossiles indirectement par un changement dans le taux d'intérêt d'équilibre. Nous montrons dans un modèle simple que l'effet indirect peut être si fort que les niveaux d'extraction augmentent avec le progrès technologique.
\end{abstract}

Mots clés : Ressources naturelles, Progrès technologique, Le Paradoxe Vert.

This paper demonstrates that technological progress in production of renewable energy can influence the extraction path of fossil fuels indirectly by a change in the equilibrium interest rate. We show in a simple model that the indirect effect can be so strong that first-period or even aggregate extraction levels rise with technological progress.

Key words: Natural Resources, Technical progress, The Green Paradox.

Codes JEL : Q31, Q42

${ }^{*}$ CIRANO and Department of Economics, McGill University, (Ngo.Long@ mcgill.ca)

${ }^{\dagger}$ Department of Economics, University of Tuebingen, Frank.Staehker@uni-tuebingen.de 


\section{Introduction}

It is a wide-spread belief that technological progress is the key to a sustainable future in which an economy will rely less on exhaustible resources, but predominantly on renewable resources. This is an obvious conclusion if renewable resources are able to substitute exhaustible resources completely. However, given the strong reliance on exhaustible resources, it seems as if exhaustible resources will still play an important role as an input into production and consumption. Thus, it seems reasonable to discuss green technological progress in an environment in which exhaustible and renewable resources are concurrently in use. ${ }^{1}$ The purpose of this paper is to show that in such a framework, general equilibrium effects of technological progress of a backstop technology can yield some interesting results: the progress may induce a rise in the rate of interest, resulting in increases in current extraction (and possibly aggregate extraction) of the exhaustible resources.

We conduct our analysis using an intentionally simple two period model in which all markets, including the market for future consumption goods, are perfectly competitive. Furthermore, we confine our analysis to the case in which the exhaustible resource is not completely exhausted in equilibrium so we may also consider changes in aggregate extraction. Our model clearly demonstrates that general equilibrium effects can be important: it can be perilous to ignore general equilibrium repercussions. ${ }^{2}$ The innovation of our paper is that by endogenizing the interest rate, we identify the interest rate channel by which indirect effects of green technological progress can dominate its direct effects, thereby leading to increased extraction.

\section{The model}

We employ a two period model of resource extraction. In any period $t, t \in\{1,2\}$, a composite (numeraire) good $Y_{t}$ is produced using energy, $E_{t}$, and a composite factor,

\footnotetext{
${ }^{1}$ Thus we depart from a common assumption in resource economics: a so-called backstop technology comes on stream to replace exhaustible resources only when they have become too expensive, ruling out the simultaneous use of both the exhaustible resource and the renewable resource. (See e.g. Hoel, 1978, 1983, 2008, Dasgupta and Heal, 1979, Dasgupta and Stiglitz, 1981)

${ }^{2}$ Even in a partial equilibrium setup, intertemporal responses can be different to those in a purely static model (see for example Hoel, 2008, 2011, Sinn, 2008, and Welsch and Stähler, 1990). Papers which have a general equilibrium flavor, however, are either too complex to isolate the interest rate effect (Ploeg and Withagen, 2012), or assume utilities that are linear in the numeraire (Grafton et al., 2012) or set the interest rate to zero (Eichner and Pethig, 2011).
} 
denoted by $K_{y_{t}}$, where the subscript denotes the use of the factor. ${ }^{3}$ Energy $E_{t}$ can be obtained from fossil fuel $R_{t}$ and from renewable resources denoted by $x_{t}$, and both are perfect substitutes such that $E_{t}=R_{t}+x_{t}$. The backstop technology allows to convert the composite output into (renewable) energy, denoted by $x$. To produce one unit of $x$ in period $t$ one must use $\lambda$ units of the composite good where $\lambda$ is the technological parameter. We assume $\lambda$ is the same for both periods. The net output of the composite good, intended for consumption and denoted by $Q$, is equal to $Q_{t}=Y_{t}-\lambda x_{t}=F\left(R_{t}+x_{t}, K_{y_{t}}\right)-\lambda x_{t}$. We assume that the production function is of Cobb-Douglas type such that $f\left(e_{t}\right)=e_{t}^{\beta}$ with $e_{t}=E_{t} / K_{y_{t}}$ and $0<\beta<1$.

To extract the quantity $R_{t}$, the representative extracting firm must use the composite factor, and we denote by $K_{R_{t}}$ the use of this factor in resource extraction. We assume rising extraction costs; and the input of the composite factor required in period 2 depends on how much was extracted in period 1. The input requirements for the two periods are given by

$$
K_{R_{1}}=\frac{1}{2} R_{1}^{2}, \quad K_{R_{2}}=\theta R_{1} R_{2}+\frac{1}{2} R_{2}^{2},
$$

where $\theta \in[0,1]$ measures the strength of the required increase in extraction inputs due to rising costs across both periods. We close the supply side of model by the factor market clearing condition for the composite factor and the stock-flow condition that the sum of extractions over the two periods must not exceed the available stock $S$, that is $K_{y_{t}}+K_{R_{t}}=K$, and $R_{1}+R_{2} \leq S$, where $K$ is a constant in both periods. The demand side of the model is given by the behavior of a representative consumer who maximizes her intertemporal utility $U\left(c_{1}, c_{2}\right)$ subject to $c_{1}+(1 /(1+i)) c_{2}=W_{0}$ where $W_{0}$ is endogenous and equal to the sum of discounted incomes. For the sake of simplicity, we assume that $K$ is fixed (no accummulation), and storing the consumption good is not possible, which implies that $c_{t}=Q_{t}$. The utility function $U(\cdot)$ is well-behaved such that $U_{1}>0, U_{2}>0, U_{11}<0, U_{22}<0, U_{12} \geq 0$ and $U_{11} U_{22}-U_{12}^{2}>0$ where the subscripts denote partial derivatives w.r.t. consumption in the respective period. Utility maximization leads to

$$
U_{1}\left(Q_{1}, Q_{2}\right)-(1+i) U_{2}\left(Q_{1}, Q_{2}\right)=0 .
$$

\footnotetext{
${ }^{3}$ Having a (composite) factor of production allows us to incorporate the income effects of green technological progress in a simple yet meaningful way.
} 
In this paper we focus on the case that the resource is not completely exhausted, that is, $R_{1}+R_{2}<S .{ }^{4}$ Since the resource is used simultaneously with the backstop technology, it must be the case that the final good producers are paying the same price for both energy inputs, i.e., $\lambda=F_{E_{t}} \equiv f^{\prime}\left(e_{t}\right)$. Then the factor price of the composite factor is $w=f\left(e_{t}\right)-e_{t} f^{\prime}\left(e_{t}\right)$. Note that this factor price is endogenously determined and that its time invariance is an equilibrium result, due to the assumption that $\lambda$ is the same for both periods. Resource owners choose $R_{1}$ and $R_{2}$ to maximize the discounted sum of profit $\lambda R_{1}-w K_{R_{1}}+(1 /(1+i))\left[\lambda R_{2}-w K_{R_{2}}\right]$. Let us define the input price ratio

$$
\delta \equiv \frac{\lambda}{w(\lambda)}=\frac{\lambda}{(1-\beta)\left(\frac{\lambda}{\beta}\right)^{\frac{\beta}{\beta-1}}}, \frac{d \delta}{d \lambda}=\frac{1}{(1-\beta) w}>0 .
$$

where we have used the equilibrium factor price. ${ }^{5}$ An increase in the efficiency of the backstop technology (a fall in $\lambda$ ) is equivalent to a decrease in $\delta$. Rewriting $w$, we see the effect of technological progress on the factor price of the composite factor,

$$
w(\delta)=(1-\beta)^{(1-\beta)} \beta^{\beta} \delta^{-\beta}, \frac{d w}{d \delta}=-\beta \frac{w}{\delta},
$$

whose size depends on the importance of the composite factor as measured by $\beta$. Using $\bar{e}=$ $\left(x_{t}+R_{t}\right) / K_{y_{t}}$, the net output in each period can be expressed as $Q_{t}=w K+\left(\lambda R_{t}-w K_{R_{t}}\right)$ so that the net output is equal to the payment to the composite factor plus the pure profit of the resource-extracting sector. Since $R_{1}>0$ and $R_{2}>0$ and the resource is not exhausted, the marginal resource rent must be zero. Solving for extractions, we obtain

$$
\begin{gathered}
R_{1}=\delta\left(\frac{1+i-\theta}{1+i-\theta^{2}}\right), \\
R_{2}=\delta\left(\frac{1+i-\theta-i \theta}{1+i-\theta^{2}}\right) .
\end{gathered}
$$

Differentiation yields

\footnotetext{
${ }^{4}$ In Long and Stähler (2012), we employ a more specific model and consider also the case of exhaustion. The case of exhaustion, however, is less interesting because aggregate extraction is fixed and green technological progress can only change the time path of extraction.

${ }^{5}$ Since $f^{\prime}\left(e_{t}\right)=\beta e_{t}^{\beta-1}=\lambda$ is constant across both periods, the energy intensity is also constant such that $e_{t}=\bar{e}=(\lambda / \beta)^{1 /(\beta-1)}$, and therefore $w=f\left(e_{t}\right)-e_{t} f^{\prime}\left(e_{t}\right)=(1-\beta) \bar{e}^{\beta}$.
} 


$$
\begin{aligned}
\frac{\partial R_{1}}{\partial i} & =\frac{\delta \theta(1-\theta)}{\left(1+i-\theta^{2}\right)^{2}}>0, \frac{\partial R_{2}}{\partial i}=-\frac{\delta \theta^{2}(1-\theta)}{\left(1+i-\theta^{2}\right)^{2}}<0, \\
\frac{\partial R_{1}}{\partial i}+\frac{\partial R_{2}}{\partial i} & =\frac{\delta \theta(1-\theta)^{2}}{\left(1+i-\theta^{2}\right)^{2}}>0, \\
\frac{\partial R_{1}}{\partial \delta} & =\frac{1+i-\theta}{1+i-\theta^{2}}>\frac{\partial R_{2}}{\partial \delta}=\frac{1+i-\theta-i \theta}{1+i-\theta^{2}}>0,
\end{aligned}
$$

and shows that (i) at a constant $i$, both extraction levels decline with technological progress, but that the effect is larger for period 1 extractions, and that (ii) an increase in the interest rate increases (decreases) period 1 (2) extractions and increases aggregate extraction. We find that an equilibrium, with simultaneous use of the backstop technology and resources in both periods and no exhaustion as given by (5), (6) and (2), exists if both the resource stock and the capital stock are not too small, and that $Q_{1}>Q_{2} \cdot{ }^{6}$

We now scrutinize the potential ambiguity of technological progress on the resource extraction path. We find:

Proposition 1 The effect of technological progress on the interest rate and resource extractions is ambiguous. If the interest rate increases sufficiently with technological progress, (i) first period extraction will increase, (ii) second-period extractions will decline and (iii) aggregate extractions will increase.

Proof: See Appendix.

What is the intuition for the ambiguity for the interest rate? Technological progress has a positive income effect which increases consumption in both periods. If the interest rate stayed constant, resource extractions would decline in both periods, but from eq. (9) we see that the effect is smaller for the second period. This direct effect on resource extractions, if acting in isolation, would, ceteris paribus, lead to a stronger decline in the supply of output in period 1 compared to period 2. However, at constant interest rate, the technological progress alone increases output in both periods. Taking both effects together, at constant interest rate, the output increase in period 2 can be greater than in period 1. The effects on consumer behavior now depend on the intertemporal utility function. Suppose that this utility function exhibits a sufficiently strong preference for

\footnotetext{
${ }^{6}$ Proofs are available upon request.
} 
present goods. To induce consumers to increase the ratio of second period consumption to first period consumption in this case, the interest rate must rise as to clear the market for future consumption goods. If this increase in the interest rate is large enough, the indirect effect will outweigh the direct effect of technological progress of the competing backstop technology, resulting in an increase in period 1 resource extractions. Even more, although second-period extractions must decline when they increase in the first period, the interest rate effect can be so strong that aggregate resource extractions may increase with technological progress.

\section{Concluding remarks}

In this paper, we have deliberately employed a very simple general equilibrium model of resource extractions in the presence of a backstop technology. We have shown that technological progress has an income effect which may not lead to resource-saving behavior. We also expect that similar results may arise when considering other effects, for example the effects of taxing resource uses. We do not claim the universal dominance of our effect, but we would like to advise that general equilibrium effects may lead to unwarranted side-effects. Of course, our results certainly rely on our assumption that production must be equal to consumption in each period. If we think of the composite factor as capital and allow investment, intertemporal consumption patterns could be smoothed. However, it seems that the interest rate effect could still be present. Furthermore, if investment augments the capital stock, it will make the marginal product of resource inputs increase and potentially add another extraction-increasing effect. In any case, it seems to us that the assumption of a constant interest rate may ignore important general equilibrium effects if the problem at hand is of significance.

\section{References}

[1] Dasgupta, P. S. and G.M. Heal (1979), Economic Theory and Exhaustible Resources. Cambridge Economic Handbooks, Cambridge University Press.

[2] Dasgupta, P. and J.E. Stiglitz (1981), "Resource Depletion under Technological Uncertainty", Econometrica 49: 85-104. 
[3] Eichner, T. and R. Pethig (2011), "Carbon Leakage, the green paradox, and perfect future markets", International Economic Review, 52: 767-805.

[4] Grafton, Q., T. Kompas and N.V. Long (2012), "Substitution between biofuels and fossil fuels: is there a Green Paradox?", Journal of Environmental Economics and Management, 64: 328-341.

[5] Hoel, M. (1978), "Resource Extraction, Substitute Production, and Monopoly,", Journal of Economic Theory, 19: 28-77.

[6] Hoel, M. (1983), “ Monopoly Resource Extractions under the Presence of Predetermined Substitute Production ", Journal of Economic Theory, 30: 201-212.

[7] Hoel, M. (2008), "Bush Meets Hotelling: Effects of Improved Renewable Energy Technology on Greenhouse Gas Emissions", CESifo Working Paper No. 2492.

[8] Hoel, M. (2011), "The Green Paradox and Greenhouse Gas Reducing Investment", International Review of Environmental and Resource Economics, 5: 353-379.

[9] Long, N.V. and F. Stähler (2012), "Resource Extraction and Backstop Technologies in General Equilibrium", paper presented at the CESifo Venice Summer Institute The Theory and Empirics of The Green Paradoxon.

[10] Ploeg, F. van der, and C. Withagen (2012), "Is There Really a Green Paradox?", Journal of Environmental Economics and Management, 64: 342-363.

[11] Sinn, H.-W. (2008), "Public Policies Against Global Warming: A Supply-Side Approach", International Tax and Public Finance, 15: 360-394.

[12] Welsch, H. and F. Stähler (1990), "On Externalities Related to the Use of Exhaustible Resources", Journal of Economics, 51: 177-195.

\section{Appendix}

We rewrite the equilibrium conditions, (5), (6) and (2) as

$$
\begin{aligned}
& f(\cdot)=\left(1+i-\theta^{2}\right) R_{1}-\delta(1+i-\theta)=0, \\
& g(\cdot)=\left(1+i-\theta^{2}\right) R_{2}-\delta(1+i)(1-\theta)=0, \\
& h(\cdot)=(1+i) U_{2}\left(Q_{1}, Q_{2}\right)-U_{1}\left(Q_{1}, Q_{2}\right)=0,
\end{aligned}
$$

where 


$$
\begin{aligned}
Q_{1} & =w\left(K+\delta R_{1}-\frac{1}{2} R_{1}^{2}\right) \\
Q_{2} & =w\left(K+\delta R_{2}-\theta R_{1} R_{2}-\frac{1}{2} R_{2}^{2}\right)
\end{aligned}
$$

Total differentiation yields

$$
\underbrace{\left[\begin{array}{ccc}
f_{R_{1}} & 0 & f_{i} \\
0 & f_{R_{1}} & g_{i} \\
h_{R_{1}} & 0 & h_{i}
\end{array}\right]}_{=A}\left[\begin{array}{c}
d R_{1} \\
d R_{2} \\
d i
\end{array}\right]=\left[\begin{array}{c}
-f_{\delta} \\
-g_{\delta} \\
-h_{\delta}
\end{array}\right] d \delta
$$

where

$$
f_{R_{1}}=g_{R_{2}}=1+i-\theta^{2}>0, f_{i}=R_{1}-\delta<0, g_{i}=R_{2}-\delta(1-\theta)>0,
$$

because $R_{1}<\delta$ and

$$
\begin{gathered}
R_{2}=\delta \frac{(1+i)(1-\theta)}{1+i-\theta^{2}}>\delta(1-\theta) \Leftrightarrow 1+i>1+i-\theta^{2}, \\
f_{\delta}=-(1+i-\theta)<0, g_{\delta}=-(1+i)(1-\theta)<0, \\
h_{R_{1}}=\left((1+i) U_{12}-U_{11}\right) w\left(\delta-R_{1}\right)-w \theta R_{2}\left((1+i) U_{22}-U_{12}\right)>0, \\
h_{R_{2}}=w\left((1+i) U_{22}-U_{12}\right)\left(\delta-\theta R_{1}-R_{2}\right)=0
\end{gathered}
$$

because $\theta R_{1}+R_{2}=\delta$,

$$
\begin{gathered}
h_{i}=U_{2}>0 \\
\left.h_{\delta}=\left((1+i) U_{22}-U_{12}\right)\left(w R_{2}-\frac{\beta Q_{2}}{\delta}\right)-\left((1+i) U_{11}-U_{12}\right)\right)\left(w R_{1}-\frac{\beta Q_{1}}{\delta}\right) .
\end{gathered}
$$

Note that $h_{\delta}$ is ambiguous in sign, and that this ambiguity implies that the direct effect of a technology change on the interest rate, that is

$$
\left.\frac{d i}{d \delta}\right|_{d R_{1}=d R_{2}=0}=-\frac{h_{\delta}}{h_{i}}
$$


is ambiguous. Expanding the matrix $A$ along the first row yields the determinant

$$
\operatorname{det}(A)=f_{R_{1}}\left(f_{R_{1}} h_{i}-f_{i} h_{R_{1}}\right)>0
$$

which proves that the equilibrium is unique. Define

$$
A_{1}=\left[\begin{array}{ccc}
-f_{\delta} & 0 & f_{i} \\
-g_{\delta} & f_{R_{1}} & g_{i} \\
-h_{\delta} & 0 & h_{i}
\end{array}\right], A_{2}=\left[\begin{array}{ccc}
f_{R_{1}} & -f_{\delta} & f_{i} \\
0 & -g_{\delta} & g_{i} \\
h_{R_{1}} & -h_{\delta} & h_{i}
\end{array}\right], A_{3}=\left[\begin{array}{ccc}
f_{R_{1}} & 0 & -f_{\delta} \\
0 & f_{R_{1}} & -g_{\delta} \\
h_{R_{1}} & 0 & -h_{\delta}
\end{array}\right]
$$

so that the changes with $\delta$ are given by

$$
\frac{d R_{1}}{d \delta}=\frac{\operatorname{det}\left(A_{1}\right)}{\operatorname{det}(A)}, \frac{d R_{2}}{d \delta}=\frac{\operatorname{det}\left(A_{2}\right)}{\operatorname{det}(A)}, \frac{d i}{d \delta}=\frac{\operatorname{det}\left(A_{3}\right)}{\operatorname{det}(A)}
$$

according to Cramer's Rule. Since $\operatorname{det}(A)>0$, the signs of the changes are given by $\operatorname{sign}\left(d R_{1} / d \delta\right)=\operatorname{sign}\left(\operatorname{det}\left(A_{1}\right)\right), \operatorname{sign}\left(d R_{2} / d \delta\right)=\operatorname{sign}\left(\operatorname{det}\left(A_{2}\right)\right), \operatorname{sign}(d i / d \delta)=$ $\operatorname{sign}\left(\operatorname{det}\left(A_{3}\right)\right)$ where the determinants

$$
\begin{aligned}
\operatorname{det}\left(A_{1}\right) & =f_{R_{1}}\left(-f_{\delta} h_{i}+f_{i} h_{\delta}\right) \\
\operatorname{det}\left(A_{2}\right) & =f_{R_{1}}\left(-g_{\delta} h_{i}+g_{i} h_{\delta}\right)+f_{\delta}\left(-g_{i} h_{R_{1}}\right)+f_{i} g_{\delta} h_{R_{1}} \\
\operatorname{det}\left(A_{3}\right) & =f_{R_{1}}\left(-h_{\delta} f_{R_{1}}+h_{R_{1}} f_{\delta}\right)
\end{aligned}
$$

are all ambiguous in sign. If the direct effect on the interest rate for given resource extractions, measured by $h_{\delta}$, and the responsiveness of first period resource extraction to the interest rate, measured by $f_{i}$, are sufficiently strong, first-period extraction will go up with technological progress, that is, $d R_{1} / d \delta<0 . h_{\delta}>0$ implies $d R_{2} / d \delta>0$ because the interest rate has the opposite effect on the response of second-period extraction to the interest rate $\left(g_{i}<0\right)$.

Now consider aggregate resource extraction $R_{1}+R_{2}$, and we find that $\operatorname{det}\left(A_{1}\right)+\operatorname{det}\left(A_{2}\right)$ has the same sign as $d\left(R_{1}+R_{2}\right) / d \delta$ and is ambiguous because

$$
\operatorname{det}\left(A_{1}\right)+\operatorname{det}\left(A_{2}\right)=\underbrace{f_{R_{1}} h_{\delta}\left(f_{i}+g_{i}\right)}_{- \text {if } h_{\delta}>0}+\underbrace{f_{R_{1}}\left(-f_{\delta}\right) h_{i}+f_{R_{1}}\left(-g_{\delta}\right) h_{i}+f_{\delta}\left(-g_{i} h_{R_{1}}\right)+f_{i} g_{\delta} h_{R_{1}}}_{+}
$$

as

$$
f_{i}+g_{i}=R_{1}+R_{2}-\delta-\delta(1-\theta)=-\frac{\delta(1-\theta)^{2} \theta}{1+i-\theta^{2}}<0
$$

